\title{
Relationship between Financial Development and Economic Growth: Empirical Evidence in Indonesia
}

\author{
Hafnida Hasan ${ }^{1}$ \\ ${ }^{1}$ Accounting and Finance Department, Applied Science University, Kingdom of Bahrain \\ Correspondence: Hafnida Hasan, Accounting and Finance Department, Applied Science University, 5055, \\ Kingdom of Bahrain. E-mail: hafnida.hasan@asu.edu.bh
}

Received: October 8, 2018

Accepted: October 26, 2018

Online Published: November 5, 2018

doi:10.5539/ijef.v10n12p37

URL: https://doi.org/10.5539/ijef.v10n12p37

\begin{abstract}
The aim of this paper to examine the relationship between financial development and economic growth in Indonesia by using data from 1986 until 2014. Johansen co-integration and Granger causality are utilized to analyze the data. The financial development is measured by the ratio of broad money and other control variables such as trade openness and government expenditure. The finding indicates that there is long run relationship between financial development and economic growth. Meanwhile, a unidirectional relationship had been found, it come from economic growth to financial development. Therefore, a policy to increase economic growth will push forward in proper to improve financial development in Indonesia.
\end{abstract}

Keywords: financial development, economic growth, Indonesia

\section{Introduction}

The relationship between financial development and economic growth has attracted improvements in the banking industry and other financial intermediaries. Hence, financial development is one important tools for economic growth. It acts as a dynamic participant in channeling assets from surplus units to deficiency agents. However, there are many different views from past literatures on how financial development is related to economic growth (Schumpeter, 1911; Robinson, 1952; Goldsmith, 1969; King \& Levine, 1993; De Gregoria \& Guidotti, 1995).

It started by Schumpeter (1911), which argued that financial development as play role for the economic growth. Meanwhile, Robinson (1952) noted that financial development is a minor factor for growth. However, Lucas (1988) mentioned that the over-stressed of financial development in promoting economic growth. Subsequent work by King and Levine (1993) found that the development on financial sector has positive significantly on economic growth and it enhances the accumulation of physical capital.

On the perpectives of economic, the causality between economic growth and fincnial development can divided into three categories. First is supply-leading view means financial development lead to economic growth (King and Levine, 1993; Christopoulos \& Tsionas, 2004; Gries, Kraft, \& Meierrieks, 2009). Second is demand-following indicates that economic growth will lead to financial development (Odhiambo, 2008; Odhiambo, 2011). Lastly, there were previous studies found two ways of causalitybetween financial development and economic growth ((Bangake \& Eggoh, 2011; Hassan, Sanchez, \& Yu, 2011; Kar, Nazlioglu, \& Agir, 2011). Therefore, it could be concluded that the previous studies have shown that there are different views on the link between financial development and economic growth. Hence, this provides a research gap since the result might depend on the number of countries, time period and the proxies of financial development used in the studies.

This paper will divided as follows: the empirical and theoretical litearute from previous studies will explained in section 2. The data and methodology used in this paper will determined in section 3, meanwhile section 4 highlight the analysis and empirical findings. Finally, the conclution as well as the implication of study will presented in section 5 .

\section{Literature Review}

The relationship between financial development and economic growth given much attention in development economics literature. King and Levine (1993) found that all proxy of financial development gave positive signs 
and statistically significant on growth in eighty countries from period 1960-1989. Rajan and Zingales (1998) investigated a multiple regressions model using data from the Industries Statistics Year Book for 1993. They found that financial development influenced directly to the economic growth. Another study by Kar and Pentecost (2000), with using granger causality, co-integration and VECM to investigate the causality between financial development and economic growth in Turkey during 1963 to 1995. The result indicated that the causality was come from economic growth to financial development, thus economic growth lends strength to the financial sector in Turkey.

Furthermore, ten developing countries were also becoming the subject empirical study done by Christopoulos and Tsionas (2004) through which they target to examine financial depth and economic growth for long run by employing the analysis of panel co-integartion. They found that there is long run relationship between growth, subsidiary variable and financial depth. Meanwhile, the causality found from financial depth to economic growth. On the other hand, Al-Tammam (2005) found that there is co-integration between financial development and economic growth in Oman, Saudi Arabia and Kuwait. Meanwhile, the causality runs from eeconomic growth lead financial development in all countries for long run and the causality runs from financial development to economic growth only for Saudi Arabia and Oman in the short run.

Furthermore, Odhiambo (2008) investigated the causality between finance and economic growth in Kenya during 1969-2005 period. It employed the dynamic tri variate Granger causality test and error correction model. $\mathrm{He}$ found that there was only one way causality from economic to finance. The finding indicated that finance act minor role in contribution to economic growth. By using the same method to analyze in 2011, he found the same result that economic growth leads financial development in South Africa for 1960-2006 period. Therefore, he concluded that the hypothesis of financial development causes economic growth did not hold in South Africa for the period of analysis.

Gries, Kraft, and Meierrieks (2009) conducted the Hsiao Granger method, the Vector Auto-Regression (VAR), and the Vector Error Correction Model (VECM) for the purpose causal relationship between financial deepening, trade openness and economic growth in 16 Sub-Saharan African countries. The results show to support the hypothesis that finance lead to economic growth. By using panel co-integration test, dynamic OLS and panel VECM approach, Bangake and Eggoh (2011) reported that there existed bi-directional causality among financial development and economic growth in 71 countries including 18 developing countries from 1960 to 2004. On the other hand, Kar, Nazliogu, and Agir (2011), focused on the Middle East and North Africa (MENA) countries for the period of 1980 to 2007. They used a simple linear model. They also found that there is two-way directional relationship between financial development indicator specific and economic growth.

Shittu (2012) examined the impact of financial intermediation on economic growth in Nigeria from 1970 to 2010. For the analysis, the unit root test and co-integration test were done accordingly and VECM was estimated using Engle-granger technique. The findings revealed that financial intermediation has a significant impact on economic growth in Nigeria. Musamali, Nyamongo, and Moyi (2014) examined the relationship between financial development and economic growth from 50 African countries for period 1980-2008. The result found that there was a positive relationship between financial development and economic growth. However, the link on domestic credit to private sector and economic growth was much stronger than that of the broad money and economic growth. In addition, there was bi-directional link between financial sector and economic growth.

Altaee and Al-Jafari (2015) investigated the relationship between trade openness, financial development and economic growth in Bahrain from 1980-2012. The VECM model in combination with VDC and IRFs analysis were utilized to explore the causality among variables. The findings show that trade openness and financial development lead economic growth. Thus, Bahrain should to push forward the improvement of financial sector and enhance trade openness to achive the sustainable of greater and higher economic growth.

Ndako (2017) found that financial development, investment and economic growth have long run relationship in Nigeria from 1960 until 2014 by conducted VAR framework of Johansen. The results also shown that investment is a critical factor through which financial development impacts on economic growth. Al-Qudah (2017) investigated the correlation between financial development and economic growth in Jordan by using quarterly data for the period 1993:Q1 to 2014:Q2. He found that financial development has a positive influence and significantly on economic growth in long run as well as there is bi-directional causality among that variables.

On the other hand, by using VAR model Jung (2017) found that real GDP per capita, financial development, real exports and real imports are co-integrated with one vector. It also shown support of supply leading view from financial development to economic growth in Korea from 1961 to 2013. By susing VECM model, Ono (2017) examined the finance-growth nexus in Russia. The period divided with two, first from 1999 through 2008 and 
second from 2009 through 2014. The findings revealed that economic growth granger cause money supply and bank lending following from 1999 to 2008. Meanwhile, the causality only run from economic growth to bank lending for 2009 to 2014.

By using ARDL approach Inheanacho (2016), found that insignificantly negative in the long run and significantly negative in the short run in Nigeria over the period 1981-2011. Similar study was conducted by Puatwoe and Piabuo (2017) found that in short run, broad money, government expenditure and economic growth have positive relationship. Meanwhile, all indicators show potive impact and significantly on economic growth in Camerron from 1980-2014. In addition, Ofori-Abebrese, Pickson and Diabah (2017) also applied ARDL approach and granger causality in Ghana during the period 1970-2013. The findings indicated that the credit from domestic to private sector has positive impact and statistically significant on the economic growth. It also found the causality from the economic growth to domestic deposit.

In addition, Okpara et al., (2018) investigated relationship between financial development and economic growth in Nigeria from 1981 until 2014. By employed co-integration and VECM, it found that financial development and economic growth have long run relationship. Besides that, it also found bi-directional causality between capital market and economic growth, while market capitalization ratio, broad money and the rate system banking of financing the economy drive the economic growth with no feedback effect.

\section{Method}

This paper applies empirical analysis with concerning on some variables such as gross domestic product, financial development, trade openness and government spending in Indonesia. All the data were collected from the statistic of World Bank during 1986 until 2014. The equations established is as follows:

$$
L G D P_{t}=\alpha+\beta_{1} L F D_{t}+\beta_{2} L G O V_{t}+\beta_{3} L T O_{t}+\varepsilon_{t}
$$

Where GDP is gross domestic product, FD is financial development, GOV is government expenditure, TO is trade openness, INF is inflation and $\varepsilon$ is error term. First, unit root test was determined to check the stationary of each variable either at level or first difference (Seddighii, Lawler \& Katos, 2000). The unit root test hypothesis is:

$$
\begin{gathered}
H_{0}: \mu=0 \text { (the existance of unit root test/not stationary) } \\
H_{a}: \mu \neq 0 \text { (no existance of unit root test/ stationary) }
\end{gathered}
$$

Augmented Dickey Fuller (ADF) test is used for unit root test and the equation will be:

$$
\Delta Y_{t}=\alpha_{0}+\sum_{j=1}^{a} \gamma_{1} Y_{t-1}+\sum_{k=1}^{b} \delta_{k} \Delta Y_{t-1}+\varepsilon_{t}
$$

Without constant and linear trend:

$$
\Delta Y_{t}=\beta Y_{t-1}+\theta_{t}
$$

With Constant:

$$
\Delta Y_{t}=\alpha+\beta Y_{t-1}+\theta_{t}
$$

With Constant and linear trend

$$
\Delta Y_{t}=\alpha+\sigma T+\beta Y_{t-1}+\theta_{t}
$$

Where $\mathrm{Y}$ refers to dependent as well as independent variables, $\Delta$ is the first differentiation, $\varepsilon t$ and $\mu \mathrm{t}$ is a random error. Next, the Johansen co-integration tests is used to examine the long run relationship between all variables. Johansen co-integration hypothesis is:

$$
\begin{aligned}
& H_{0}: \mu=0(\text { no existance of co }- \text { integartion }) \\
& H_{a}: \mu \neq 0(\text { the existance of co }- \text { integration })
\end{aligned}
$$

The Johansen co-integration equation is as follows:

$$
Y_{t}=\gamma_{1}+\gamma_{2} X_{t}+\theta_{t}
$$

And the residual equation is:

$$
\widehat{\theta_{t}}=Y_{t}-\widehat{\gamma_{1}}-\widehat{\gamma_{2}} X_{t}
$$

Johansen co-integration test is based on Vector Autoregressive (VAR) analysis, is as mentioned below:

$$
Y_{t}=\beta_{1} Y_{t-1}+\cdots+\beta_{x} Y_{t-x}+b x_{1}+\varepsilon_{t}
$$

Next, we conducted the granger causality is used the existence of causal relationship between two variables, and the equation is as follows: 


$$
\begin{array}{r}
Y_{i}=\beta_{0}+\sum_{z=1}^{p} \delta_{z} Y_{t-z}+\sum_{i=1}^{q} \gamma_{i} X_{t-1}+\varepsilon_{t} \\
X_{i}=\propto_{0}+\sum_{z=1}^{p} \rho_{z} X_{t-z}+\sum_{i=1}^{q} \mu_{i} Y_{t-1}+\theta_{t}
\end{array}
$$

\section{Results}

In this parts are discussed the findings from the tests based on the all of variables. Unit root test was employed to measure the level stationary of time series data based on Augmented Dickey-Fuller (ADF) (see Table 1).

Table 1. Unit root test results

\begin{tabular}{ccccc}
\hline \multirow{2}{*}{ Variables } & \multicolumn{2}{c}{ Intercept } & \multicolumn{2}{c}{ Trend and intercept } \\
\cline { 2 - 4 } & Level & $1^{\text {st }}$ difference & -1.991 & $1^{\text {st }}$ difference \\
\hline \multirow{2}{*}{ LGDP } & -0.504 & $-5.474^{* * *}$ & $(0.582)$ & $-5.353^{* * *}$ \\
& $(0.876)$ & $(0.001)$ & -2.512 & $(0.0009)$ \\
\multirow{2}{*}{ LFD } & -1.748 & $-3.035^{* *}$ & $(0.320)$ & -2.977 \\
& $(0.397)$ & $(0.044)$ & -1.933 & $(0.156)$ \\
\multirow{2}{*}{ LGOV } & -0.203 & $-5.487^{* * *}$ & $(0.612)$ & $-5.395^{* * *}$ \\
& $(0.927)$ & $(0.0001)$ & -1.904 & $(0.0008)$ \\
\multirow{2}{*}{ LTO } & -1.394 & $-4.483^{* * *}$ & $(0.627)$ & $-4.541^{* * *}$ \\
& $(0.571)$ & $(0.001)$ & $(0.006)$ \\
\hline
\end{tabular}

Note. $* * *$ and $* *$ denote statistical significance level at $1 \%$ and $5 \%$, respectively.

Table 1 above shows that all variables (financial development. Government spending, trade openness and economic growth) are integrated of order one I (d) at significance level 1\% and 5\%, hence the null of unit root test is rejected. Hence, it could say that our time series data are stationary at first difference and can proceed to test for long run co-integration.

Table 2. Co-integration test

\begin{tabular}{ccccc}
\hline \multicolumn{5}{c}{ Lag intervals to 2 } \\
\hline Rank & Max-Eigen Statistic & Critical Value (Eigen) at 5\% & Trace Statistic & Critical Value (Trace) at 5\% \\
\hline $\mathrm{r}=0^{*}$ & 38.449 & 27.584 & 69.94 & 47.85 \\
$\mathrm{r} \leq 1^{*}$ & 17.059 & 21.132 & 31.498 & 29.797 \\
$\mathrm{r} \leq 2$ & 10.961 & 14.264 & 14.438 & 15.494 \\
$\mathrm{r} \leq 3$ & 3.478 & 3.841 & 3.478 & 3.841 \\
\hline
\end{tabular}

Note. L.R test indicates two co-integrating equations at $10 \%$ level.

Table 2 above shows that there is co-integration result for the relationship between financial developments, government spending and trade openness with economic growth. From the result above, at least two variables co-integrated with economic growth in the long run. Table 3 below represents the granger causality for all variables.

Table 3. Granger causality

\begin{tabular}{lcc}
\hline Null hypothesis & Obs & F-statistic \\
\hline LFD does not granger cause LGDP & 28 & 2.496 \\
LGDP does not granger cause LFD & & $3.821^{* *}$ \\
LGOV does not granger cause LGDP & 28 & 1.540 \\
LGDP does not granger cause LGOV & 28 & 1.116 \\
LTO does not granger cause LGDP & & 0.334 \\
LGDP does not granger cause LTO & & $4.039^{* *}$ \\
\hline
\end{tabular}

The finding of granger causality shows that economic growth is granger cause to financial development, which means supporting the hypothesis of demand following. It also found that economic growth has cause the increasing of trade openness in Indonesia. 


\section{Conclusion}

This study aims to examine relationship between financial development and economic growth in Indonesia for the period 1986-2014. Financial development is a value-enhancing service (Iqbal, 2013). On the other hand, financial sectors are one of the vital sources for the growth of economy. The efficiency of financial development are able to better perform of critical functions such as decreasing transactions cost, minimizing data, monitoring cots and provide monetary supports to the growth of economy (Patrick, 1966).

The results show that for the unit root test all variables are significant at $1 \%$ and $5 \%$ level based on ADF test. Co-integration test result showed that at least two variables have long run relationship between financial development, government spending and trade openness with economic growth. Furthermore, granger causality shows that supporting of demand following from previous studies which means economic growth granger cause financial development. Therefore, Indonesian government can give priority on the restructuring of financial development to accelerate a sustainable growth for short term as well as long term.

\section{References}

Al-Qudah, A. M. (2017). Financial development and economic growth of Jordan. Research Journal of Finance and Accounting, 7(6), 143-152.

Altaee, A. H. H., \& Al-Jafari, K. M. (2015). Financial development, trade openness and economic growth: A trilateral analysis in Bahrain. International Journal Economics and Finance, 7(1), 241-254.

Al-Tammam, M. (2005). Causality between financial development and economic growth: The case of Kuwait, Oman, and Saudi Arabia. Ph.D. Dissertation, Colorado State University.

Bangake, C., \& Eggoh, J. (2011). Further evidence on finance-growth causality: A panel data analysis. Economic Modelling, 35(2), 176-188. https://doi.org/10.1016/j.ecosys.2010.07.001

Christopoulos, D. K., \& Tsionas, E. G. (2004). Financial development and economic growth: Evidence from panel unit root test and cointegration test. Journal of Development Economics, 73, 55-74. https://doi.org/10.1016/j.jdeveco.2003.03.002

De Gregio, J., \& Guidotti, P. E. (1995). Financial development and economic growth. World Development, 23(3), 433-448. https://doi.org/10.1016/0305-750X(94)00132-I

Goldsmith, R. (1969). Financial Structure and Development (1st ed). New Haven: Yale University Press.

Gries. T., Kraft, M., \& Meierrieks, D. (2009). Linkages between financial deepening, trade openness, and economic development: Causality evidence from Sub-Saharan Africa. World Development, 37(12), 1849-1860. https://doi.org/10.1016/j.worlddev.2009.05.008

Hassan, M. K., Sanchez, B., \& Yu, J. S. (2011). Financial development and economic growth: New evidence from panel data. The Quarterly Review of Economics and Finance, 51, 88-104. https://doi.org/10.1016/j.qref.2010.09.001

Iheanacho, E. (2016). The impact of financial development on economic growth in Nigeria: An ARDL analysis. Economies, 4(4), 26. https://doi.org/10.3390/economies4040026

Iqbal, M. (2013). Islamic finance: An attractive new way of financial intermediation. International Journal of Banking and Finance, 10(2), 1-24.

Jung, S. M. (2017). Financial development and economic growth: Evidence from South Korea between 1961 and 2013. International Journal of Management, Economics and Social Sciences (IJMESS), 6(2), 89-106.

Kar, M., \& Pentecost, E. J. (2000). Financial development and economic growth in Turkey: Further evidence on the causality issue. Economic Research Paper, 27.

Kar, M., Nazlioglu, S., \& Agir, H. (2011). Financial development and economic growth nexus in the MENA countries: Bootstrap panel granger causality analysis. Econometric Modeling, 28(1-2), 685-693. https://doi.org/10.1016/j.econmod.2010.05.015

King, R. G., \& Levine, R. (1993). Finance, entrepreneurship and growth: Theory and evidence. Journal of Monetary Economics, 32(3), 513-542. https://doi.org/10.1016/0304-3932(93)90028-E

Lucas Jr, R. E. (1988). On the mechanics of economic development. Journal of Monetary Economics, 22(1), 3-42. https://doi.org/10.1016/0304-3932(88)90168-7

Musamali, A. R., Nyamongo, M. E., \& Moyi, D. E. (2014). The relationship between financial development and economic growth in Africa. Research in Applied Economics, 6(2), 190-208. 
https://doi.org/10.5296/rae.v6i2.5226

Ndako, U. B. (2017). Financial development, investment and economic growth: Evidence from Nigeria. Journal of Reviews on Global Economics, 6, 33-41. https://doi.org/10.6000/1929-7092.2017.06.03

Odhiambo, N. M. (2008). Financial depth, savings, and economic growth in Kenya: A dynamic causal linkage. Economic Modeling, 25(4), 704-713. https://doi.org/10.1016/j.econmod.2007.10.009

Odhiambo, N. M. (2011). Financial intermediaries versus financial markets: A South African experience. International Business and Economic Research Journal, 10(2), 77-84. https://doi.org/10.19030/iber.v10i2.1795

Ofori-Abebrese, G., Becker Pickson, R., \& Diabah, B. T. (2017). Financial Development and Economic Growth: Additional Evidence from Ghana. Modern Economy, 8, 282-297. https://doi.org/10.4236/me.2017.82020

Okpara, G. C., Onoh, A. N., Ogbonna, B. M., \& Iheanacho, E. (2018). Econometrics Analysis of Financial Development and Economic Growth: Evidence from Nigeria. Global Journal of Management and Business Research, 18(2).

Ono, S. (2017). Financial development and economic growth nexus in Russia. Russian Journal of Economics, 3(3), 321-332. https://doi.org/10.1016/j.ruje.2017.09.006

Patrick, H. T. (1966). Financial development and economic growth in underdeveloped countries. Economic Development and Cultural Change, 14(2), 74-89. https://doi.org/10.1086/450153

Puatwoe, J. T., \& Piabuo, S. M. (2017). Financial sector development and economic growth: Evidence from Cameroon. Financial Innovation, 3(1), 25. https://doi.org/10.1186/s40854-017-0073-x

Rajan, R. G., \& Zingales, L. (1998). Financial dependence and growth. The American Economic Review, 88(3), 559-586.

Robinson, J. (1952). The Generalization of the General Theory in the Rate of Interest and Other Essays. London: Macmillan.

Schumpeter, J. A. (1911). A Theory of Economic Development. Cambridge, MA: Harvard University Press.

Seddighi, H., Lawler, K. A., Lawler, K., \& Katos, A. V. (2000). Econometrics: A practical approach. Psychology Press.

Shittu, A. I. (2012). Financial intermediation and economic growth in Nigeria. British Journal of Arts and Social Science, 4(2), 164-179.

\section{Copyrights}

Copyright for this article is retained by the author(s), with first publication rights granted to the journal.

This is an open-access article distributed under the terms and conditions of the Creative Commons Attribution license (http://creativecommons.org/licenses/by/4.0/). 